\title{
The Syro-Egyptian Sultanate in Transformation, 1496-1498. Sultan al-Nāṣir Muḥammad b. Qāytbāy and the reformation of mamlük institutions and symbols of state power
}

\author{
Albrecht Fuess
}

$1 \quad$ Introduction

When the Abbasid shadow Caliph of Cairo al-Mutawakkil died in Cairo at the end of September 1497 [end of Muharram of 903] a dispute arose between alMutawakkil's son Ya'qūb and his nephew Khalīl about who should become the new caliph. According to our main source for the period, the chronicler Ibn Iyās, Sultan al-Malik al-Nāṣir Muḥammad b. Qāytbāy summoned the two pretenders to the citadel. He listened to the different arguments of both men, until Khalīl argued that his cousin Ya'qūb lacked experience and proper judgment for the office of the caliphate. At this point in the discussion the young sultan addressed the audience and shouted in the direction of Khalil: "Was his father a Caliph?" On receiving a negative answer he said: "No one knows the caliphate from his own experience except the son of a caliph". For this reason, Ibn Iyās explained, Yā'qūb was chosen as the successor of his father. ${ }^{1}$

What is quite remarkable about this story is that it represents the only time in Ibn Iyās' 70-page account of the reign of al-Nāṣir Muhammad b. Qāytbāy that we actually hear the sultan himself talk. As this chapter will argue, this unusual episode can in fact be read as no less than the governmental program of sultan al-Nāṣir Muhammad b. Qāytbāy. Al-Nāṣir Muhammad faced similar accusations from mamlūk amirs towards his sultanate as Ya'qūb had from Khalīl. The leading officers of al-Nāșir Muhammad's father al-Ashraf Qāytbāy (r. 1468-1496) argued that al-Nāșir Muhammad totally lacked the experience they had acquired in the long years of service to the late sultan. In Ibn Iyās' story of the succession of al-Mutawakkil in 1497, this reasoning was countered by al-Nāṣir Muhammad b. Qāytbāy when he publicly claimed that no one is closer to a father than his own son.

1 Ibn Iyās, Badā’i al-zuhūr, vol. 3, 379-38o; Ibn Iyās, Histoire, Tome II, pp. 419-420. 
In order to see where the current chapter stands within the framework of this volume we first need a short contextualization. At the end of the fifteenth century, the Sultanate's state had reached a high degree of centralization and adopted a ruling system, which according to Van Steenbergen, Wing and D'hulster was formed by a steady process of "Mamlukization". As the argument goes, the Mamluk political order had a two-sided function: first "as a nondynastic idea of hegemonic political order" and second "as a coercive bureaucratic apparatus that was produced by, and that was set up to reproduce that order". ${ }^{2}$ There have been other studies in the field such as the work by Appelániz regarding the centralization of trade by sultanic agencies with novel trade procedures, or Julien Loiseau's study of the rise of civil servant families. These scholars underline the fact that the fifteenth century Sultanate had developed a distinct state model which contributed to its stability. ${ }^{3}$ At my present stage of reasoning, and with the information currently available, I would tentatively term this dualism and intertwining of the civil and military elite the "deep Mamluk state". From my point of view the "deep Mamluk state" actually meant that institutions and networks did function independently of individual sultans or civil servants while on the other hand refined selection processes in the military and administrative sector ensured the availability of a large reservoir of highly qualified personnel. In the course of the fifteenth century this meant that sons of old sultans were seen as unfit to rule as they lacked the quality of experienced leadership. Their function was reduced to that of a placeholder after the death of the old sultan until the high leading amirs of the previous sultan would choose the real successor from among their ranks. When sultan al-Ashraf Qāytbāy died in 1496 after almost thirty years of rule, however, the situation was somehow different from prior cases of sultanic successions in the fifteenth century. In the 1490 s the Sultanate faced challenges from several external military and ideological threats. On the one hand, the Sultanate's world had seen tremendous changes after the Ottoman conquest of Constantinople in 1453. This historic event made the Sultanate's leadership vigilant about the Ottomans' further moves. In 1492 Granada was taken by the forces of the Reconquista. Whereas sultan Qāytbāy and his amirs reacted only by diplomatic means, the Ottomans fought the Christians effectively. The OttomanMamluk war from 1485 and 1491 ended the Sultanate's influence over larger parts of Eastern Anatolia, and made clear that the Sultanate's mamlūk military structure had to be reformed if they wanted to withstand the Ottoman military

2 Van Steenbergen, Wing \& D'hulster, "Mamlukization of the Mamluk Sultanate?-II", p. 561.

3 Apellániz, Pouvoir et finance en méditerranée pré-moderne and Loiseau, Reconstruire la maison du sultan, vol. 1, pp. 179-214. 
machine for much longer. ${ }^{4}$ On the other hand, the Sultanate's mamlük leadership must have been aware of the European naval expansions in the Atlantic Ocean, which in 1498 would even bring the Portuguese in the Red Sea, literally turning the Sultanate's worldview upside down.

The period therefore posed tremendous challenges, and Sultan Qāytbāy had already responded by initiating various reforms. ${ }^{5}$ However, his military reforms in particular worked to the detriment of the existing elite while his financial reforms, aiming to bring in more cash, were also not much liked. Ibn Iyās dates the first use of rifles in 1490, during the Ottoman-Mamluk conflict. Qāytbāy sent awläd an-nās and other soldiers to the front equipped with guns, and after having shown their newly acquired expertise in a public display to the sultan, they were sent off to the North. ${ }^{6}$ In the aftermath of the war, then, we witness increasing moves by the Sultanate's agents in order to gain more knowledge about the usage of canons and rifles and to make contact with foreign experts. At the same time, this all meant that traditional military training and administrative proceedings had to be adjusted and sometimes fought through against the old elite, the "deep Mamluk state". The old sultan had had the prestige to carry on with these reforms and to adjust the system accordingly. When he died in 1496, however, these reforms had only begun to be initiated, the Sultanate was still under existential external threats, and the need for accommodation and adaptation remained urgent.

At this moment of insecurity, as I will argue, Qāytbāy's young son al-Nāșir Muhammad tried to put himself at the helm of these reforms and to build a power base among the new military forces and the younger mamlük leadership in order to get rid of his veteran rivals. That he succeeded, at least to a certain extent, is for me an indication of the extent of the crisis in the Sultanate's state in 1496. As I will argue more specifically below, al-Nāșir Muhammad b. Qāytbāy actually addressed this crisis also by bolstering his claims ideologically. The assumption of this chapter will be that al-Nāșir Muhammad managed this especially by making all kinds of implicit references to al-Nāșir Muhammad b. Qalāwūn (r. 1293-4/1299-1309/1310-41), a famous sultan of the fourteenth century who himself had been a son of a mamlüksultan and at the same time one of the most important rulers in the history of the Sultanate. By holding on to power and ruling successfully for over four decades, this al-Nāșir Muḥammad, son of the mamlūk ruler al-Manșūr Qalāwūn (r. 1279-1290) had come to represent a

4 Har-El, Struggle for Domination in the Middle East.

5 Petry, "The military institution and innovation in the late Mamlūk period".

6 Ibn Iyās, Badā'i al-zuhūr, vol. 3, p. 269. 


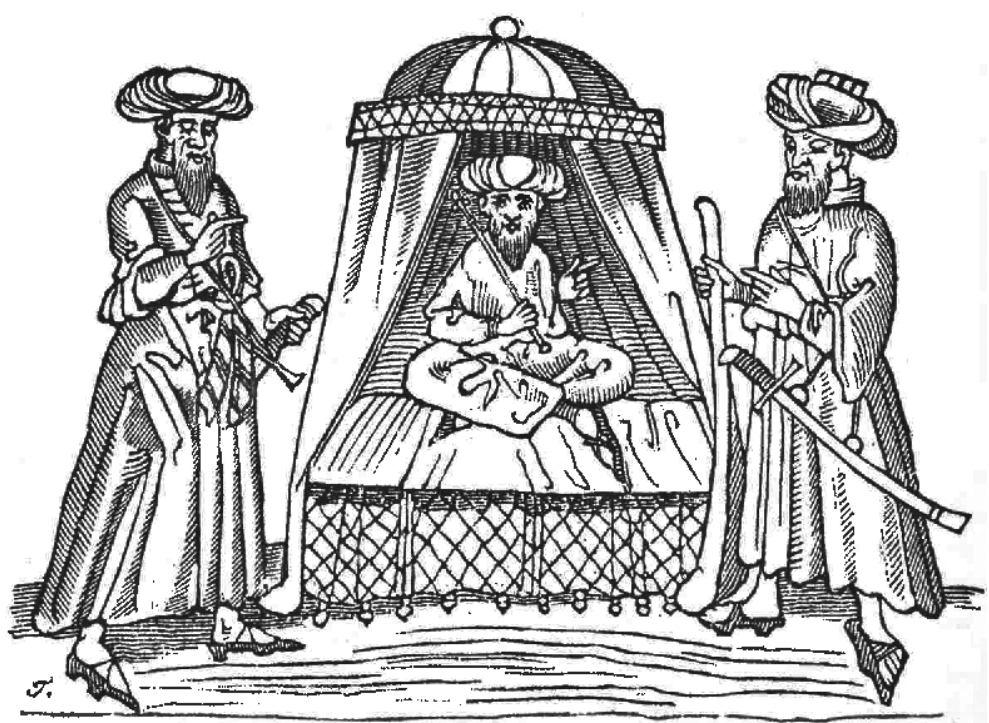

FIGURE 4.1 Sultan al-Nāṣir Muḥammad b. Qāytbāy (1496-1498)

VON HARFF, DIE PILGERFAHRT DES RITTERS ARNOLD VON HARFF, P. 90

model for later sons of mamlük rulers who argued in favor of the dynastic principle instead of meritocratic succession.

The present contribution will try to show how al-Nāșir Muhammad b. Qāytbāy tried to copy his predecessor sultan al-Nāșir Muhammad b. Qalāwūn in order to overcome the popular slogan "al-mulk 'aqim" (regency is infertile). This slogan had initially been used as propaganda against Sultan al-Nāșir Muhammad b. Qalāwūn at the beginning of the fourteenth century, but he had prevailed despite hostile agitations against him. However, under his successors, the dynastic principle weakened considerably as a means of making successful claims to the sultanate. Since the beginning of the fifteenth century "almulk 'aqim" had then developed into the factual norm regarding the Sultanate's succession procedure. ${ }^{7}$ From then on, no son managed to stay on as a new sul$\tan$ for longer periods after the death of his father, or even tried to do so. AlNāṣir Muhammad b. Qāytbāy proved in many respects to be the odd one out.

Al-Nāṣir Muhammad b. Qāytbāy was born in November 1482 [Shawwāl of 887]. ${ }^{8}$ His father sultan al-Ashraf Qāytbāy had reigned in the Sultanate from

7 Haarmann, “Der arabische Osten im späten Mittelalter, 1250-1517", p. 229.

8 Ibn Iyās, Badāiti. vol. 3, 197; Ibn Iyās, Histoire, p. 217. 
1468 to 1496 . Contemporary sources described Qāytbāy's reign as stable and prosperous and the public image one encounters in historiography is highly positive compared to the one of his son and later successors. The mother of Qāytbāy's son and successor was a Circassian slave concubine of Qāytbāy named Așalbāy. The parents called their little boy Muhammad.

Important relatives in Muhammad's life were his maternal uncle, the amir Qānșūh, and his paternal cousins Jānim and Jānibak, whose father Qait had come with them to Cairo from Cyprus in the year 900/1495. The two brothers were integrated into the mamlūk barracks and became close friends of their cousin Muhammad. ${ }^{9}$ Little Muhammad apparently also had a fond relationship with Āqbardī the powerful Great Dawādār and cousin of his father. ${ }^{10}$

Little is known about al-Nāṣir Muhammad b. Qāytbāy prior to his ascension to the throne, except the story of one event which happened when the boy was 13 years old. Around the time of the arrival of his nephews in Egypt, Sultan Qãytbāy had decided that his son should enter the mamlūk barrack of the Hippodrome, where the incoming young military slaves, who had been purchased in Central Asia, were garrisoned after their arrival in Cairo in order to receive their military training. Sultan Qāytbāy told the commander of the barrack to treat Muhammad as a simple recruit. According to Ibn Iyās this decision was the result of the anger and hate the sultan bore towards his son. After a few days the Atäbak $k^{11}$ Azbaq took the young boy into his own house, so that he would be at least separated from the others at night. ${ }^{12}$ In any case it seems that Qāytbāy wanted to prepare his son as successor by ensuring that he would have a real mamlük education and allowing him to build up a khushdāshiyya (network of comrades) of his own among the young recruits, as this was around about the same time as Muhammad's cousins entered the barracks.

When his father died in the summer of 901/1496 Muhammad was still only fourteen years old and soon found himself caught in the middle of the power struggle of the leading amirs. Ibn Iyās presents the enthronement of al-Nāșir Muhammad b. Qāytbāy as the result of the battle of the amirs who could not agree on who should become the successor among them. Therefore, they opted

Ibn Iyās, Badā̇ic vol. 3, p. 308; Ibn Iyās, Histoire, 349. Ibn al-Ḥimșī says that the brother of the Sultan had spent thirty years in Cyprus, see: Ibn al-Ḥimșī, Hawādith al-zamān, vol. 1, p. 382. Nothing is known as to whether there was a good or bad relationship between the maternal uncle and the paternal cousins.

10 Holt, "al-Nāșir".

11 The atäbak (commander in chief) represented the second highest position in the realm. Not only did he command the army but he was the sultan's deputy in case of absence. See: Sievert, Der Herrscherwechsel im Mamlukensultanat, p. 68. If this anecdote holds true, the sheltering of Muhammad at night presented a case of insubordination of the atābak against the sultan, but apparently with no consequences. 
for al-Nāṣir Muhammad b. Qāytbāy in order to gain time to settle the question of real succession at a later date. Two leading amirs were especially prominent in this affair in the aftermath of Qāytbāy's death. They were Qānșūh alKhamsamìya the new commander in chief (atābak) and Kurtbāy al-Ahmar who became Vizier, Ustādār (head of the sultan's household) and inspector of the provinces. ${ }^{13}$ Together they had already plotted against a third rival, the aforementioned cousin of Qāytbāy, Āqbardī the Great-Dawādār (the keeper of the royal inkwell) who headed the royal administration. After Āqbardī's house in Cairo had been attacked by followers of his rivals in the final days of the old sultan, he had fled and gathered troops in Syria. ${ }^{14}$

Āqbardì's return to Egypt was anticipated by many and apparently hoped for by al-Nāșir Muhammad b. Qāytbāy, who was secretly looking out for the followers of Āqbardī and then declared an amnesty for them in January 1497 [Jumādā I 902]. ${ }^{15}$ Qānșūh al-Khamsamìya responded to these steps by declaring himself sultan in February of 1497 [Jumādā I 902] and besieged the citadel where the young sultan was sheltering. In the battle which now ensued alNāṣir Muhammad b. Qāytbāy was victorious because his former comrades, the young mamlük recruits, fought for him under the command of his maternal uncle Qānșūh Moreover, a unit of black slaves with firearms was deployed very successfully during this skirmish. Qānșūh al-Khamsamìya finally fled to Syria some days later and was put to death by his arch enemy Āqbardī, the Great Dawādār. ${ }^{16}$ Afterwards the sultan promoted his uncle Qānșūh, to the rank of the inspector of beverages (shädd al-shirābkhāna). This proved to be the first step in what turned out to be an astonishing career for uncle Qānșūh. ${ }^{17}$

Meanwhile the Great Dawādār Āqbardī returned to Cairo and resumed his offices. However, almost immediately he started to plot against the young sultan and his entourage. In August of 1497 (Dhū al-Hijja 902) came the turn of Āqbardī to besiege his relative in the Citadel. He put up headquarters in the Mosque complex of Sultan Hasan beneath the citadel and attacked al-Nāșir Muhammad b. Qāytbāy and his troops from below. But although Āqbardī had hired an Italian canon caster and was in possession of firearms, he did not succeed in conquering the fortress and went back to Syria. ${ }^{18}$ In doing so he could save his head in contrast to the Italian caster Domenico who lost his, which was then shown on a pike on Bāb al-Silsila, the formal entrance to the royal court. 19

\footnotetext{
13 Ibn Iyās, Badāit. vol. 3, p. 324, 336; Ibn Iyās, Histoire, p. 366, 375.

14 Ibn Iyās, Badā̇ic vol. 3, p. 322; Ibn Iyās, Histoire, p. 363 .

15 Ibn Iyās, Badā'ic vol. 3, pp. 339, 341.; Ibn Iyās, Histoire, p. 378, 382.

16 Ibn Iyās, Badā̇ic vol. 3, pp. 343, 350; Ibn Iyās, Histoire, p. 384, 391.

17 Ibn Iyās, Badā̇ic vol. 3, p. 347; Ibn Iyās, Histoire, p. 387.

18 Ibn Iyās, Badā’ic vol. 3, pp. 366-376; Ibn Iyās, Histoire, pp. 406-416.

19 Ibn Iyās, Badā̇it. vol. 3, p. 375; Ibn Iyās, Histoire, p. 415.
} 
In Syria Âqbardi temporarily managed to take hold of $\mathrm{Gaza}^{20}$ and then tried to gain Damascus but was only able to pillage small villages in the neighborhood. He and his troops nevertheless remained active over the next two years especially in Northern Syria. ${ }^{21}$ At the end of 1497 al-Nāṣir Muhammad b. Qāytbāy declared an amnesty for Āqbardī's followers in Cairo and quite a few of them resurfaced. There were even rumors that the sultan had tried to strengthen ties with Āqbardī despite their fighting in summer. ${ }^{22}$ Finally Âqbardī managed to outlive al-Nāșir Muḥammad b. Qāytbāy and re-entered the official political scene when he was nominated as governor of Tripoli in the summer of summer 1499 (904) only to succumb to illness immediately afterwards. ${ }^{23}$

But let us return to the summer of 1497 and the victory of al-Nāșir Muhammad b. Qāytbāy against Āqbardī and his flight to Syria. We learn that al-Nāșir Muhammad b. Qāytbāy again promoted his uncle Qānșūh who at that time was around thirty years of age, to the office of Great Dawādarr. Despite this promotion in June 1498 [Dhū al-Qa'da 903] rumors reached Damascus about a fall out between the sultan and his uncle. ${ }^{24}$ In order to calm the tension the sultan's mother Așalbāy had both men summoned to the Citadel in February 1498 [Rajab 903] and made them swear in her presence on the Quran copy of the third Caliph 'Uthmān (r. 644-656) that they would not fight each other. But this oath turned out meaningless. ${ }^{25}$ High ranking officers were highly critical of the role Așalbāy played in governmental affairs. Ibn Iyās quotes Kurtbāy al-Ahmar, who had meanwhile been sent off from Cairo as viceroy of Damascus, as crying out loud in the council hall of Damascus "We are governed by a boy and a woman!"26

In September 1498 [Safar 904] the sources then speak of a heavy dispute between al-Nāṣir Muhammad b. Qāytbāy and his mother about his marriage to the Circassian lady Mișirbāy, the widow of Kurtbāy, the former governor of Gaza and brother of the former Dawādār Āqbardī. Ibn Iyās says in this context that this marriage did nothing but bring al-Nāșir Muhammad bad luck as he would be killed less than a month later. ${ }^{27}$ The political intentions behind this marriage remain unclear, but maybe given his parallel activities to grant an amnesty to the followers of Āqbardī al-Nāṣir Muhammad might have wanted to reconcile with this side of his family, especially when his maternal uncle

\footnotetext{
20 Ibn Iyās, Badāìi vol. 3, p. 378; Ibn Iyās, Histoire, p. 419.

21 Ibn Iyās, Badā̇ic. vol. 3, p. 381; Ibn Iyās, Histoire, p. 422.

22 Ibn Iyās, Badāii vol. 3, p. 383 f.; Ibn Iyās, Histoire, p. 424.

23 Ibn Iyās, Badā’ic vol. 3, p. 420 f.; Ibn Iyās, Histoire, p. 46o; Ibn al-Hiimṣ̄i, Hawādith, vol. 2, p. 78.

24 Ibn Țūlūn, Mufäkahat, vol 1, Cairo 1962, p. 197.

25 Ibn Iyās, Badāंic vol. 3, p. 387; Ibn Iyās, Histoire, p. 428.

26 Ibn Iyās, Badā’ic vol. 3, p. 406; Ibn Iyās, Histoire, p. 448.

27 Ibn Iyās, Badā̇i ${ }^{2}$. vol. 3, p. 399; Ibn Iyās, Histoire, p. 441.
} 
went astray. Al-Nāșir Muhammad's death came about in October of 1498 as he went with his two cousins Jānim and Jānibak to the Nile near Giza. There they met the Second Dawādār Tuman Bāy with his soldiers at the encampment of Taalibiyya. The sultan and his cousins did not expect an attack and were therefore slain on the spot. They fell victim to a complot which was apparently comastered by al-Nāṣir Muhammad's maternal uncle Qānșūh, who then became enthroned as the new Sultan with the regal title al-Malik al-Zāhir. ${ }^{28}$ A year later al-Zāhir Qānșūh completed his claim to the sultanate by marrying Mișirbāy, the widow of al-Nāșir Muḥammad b. Qāytbāy, as an additional wife. ${ }^{29}$ According to historical sources, she also did not bring him luck as he was himself toppled from power in June of 1500 . The story goes that upon arrival of enemy troops, Qānșūh fled in women's clothes from the citadel and that was the last to be heard of him. ${ }^{30}$

His nephew al-Nāṣir Muhammad b. Qāytbāy was buried in the Mausoleum of Qāytbāy in Cairo's Northern Cemetery, beside the tomb of his father. He was survived by his mother Așalbāy who went on to lead a remarkable life which was very closely bound to the sultanate. She was at first the concubine of Sultan Qāytbāy, then the mother of Sultan al-Nāṣir Muhammad b. Qāytbāy, later the sister of Sultan al-Zāhir Qānșūh (r. 1498-150o), then the wife of Sultan alAshraf Jān Bulāṭ (r. 1500-1501) until Sultan Qānșūh al-Ghawrī (r- 1501-1516) forced her to go into exile after her pilgrimage to Mecca in 914/1508. She died in Mecca one year later. ${ }^{31}$

The Sources

The main source for the reign of al-Nāṣir Muhammad b. Qāytbāy is the chronicle of the contemporary Egyptian scholar Ibn Iyās (d. around 1524), Badā'ic alzuhūr fì waqā̄ic al-duhūr. But Ibn Iyās deeply despised al-Nāṣir Muḥammad b. Qāytbāy, and the obituary of the ill-fated young sultan reads as follows: "He was said to have possessed an incredible generosity and that he was very brave, but he was a brute with a fast hand. He loved to spill blood, had no manners and liked the company of the lowest people in society". ${ }^{22}$ Almost everything the

28 Ibn Iyās, Badāंic vol. 3, pp. 401, 404; Ibn Iyās, Histoire, p. 444, 446.

29 Ibn Iyās, Badāंic vol. 3, p. 426; Ibn Iyās, Histoire, p. 466.

30 Ibn Iyās, Badā'ic vol. 3, p., 436; Ibn Iyās, Histoire, p. 476.; Petrus Martyr Anglerius a Spanish envoy who visited Cairo in 1501 says in contrast, that Qānșūh had been taken prisoner and brought to the Citadel of Alexandria, Anglerius, Legatio Babylonica, p. 265.

31 Ibn Iyās, Badä̉ic vol. 4, pp. 131, 159.

32 Ibn Iyās, Badā’i . vol. 3, p. 402; Ibn Iyās, Histoire, p. 444. 
young sultan did is described by Ibn Iyās as "something never heard of" and the comments always have negative connotations. For example, when the sultan commands that houses near the waterfront should be lit in the evenings, Ibn Iyās commentates this by saying that the sultan ordered it because he and his cousins wanted to look from their boat through the windows of the houses to check on the women inside. If they were pleased with what they saw they entered the house and captured the women. ${ }^{33}$

It is anyone's guess why Ibn Iyās paints this negative image of the sultan. It seems that he was a staunch supporter of the old Mamluk system of governance of Qāytbāy and his predecessors. For him a new sultan should come out of the ranks of the experienced amirs and not be the young son of the deceased ruler, and more than once Ibn Iyās complains of the foolishness of the young sultan. ${ }^{34}$ Moreover, Ibn Iyās argues that the sultan had taken away property and salaries of the descendants of mamlūks (awläd al-nās). Ibn Iyās, who was himself a grandson of a mamlük soldier, believed that such confiscations were highly deplorable as they threatened his income base. In any case, Ibn Iyās is responsible for most of the bad press which al-Nāṣir Muhammad b. Qāytbāy has received in historical writing until now. ${ }^{35}$ Other contemporary authors like Ibn al-Himși (d. 934/ 1528) and the Damascene author Ibn Țūūn (d. 953/1546) do not add much detail to the life of the sultan, but they take a more or less neutral stance. ${ }^{36}$

We find a more literary approach, which however is far more positive towards the sultan, in a work entitled al-Badr al-zāhir fì nușrat al-Malik al-Nāṣir, which Peter Holt attributes to Ibn Shiḥna (d. 921/1515) a Ḥanbali judge from Aleppo who frequently traveled to Cairo. This Ibn Shihna was an eyewitness of the defeat of Qānșūh al-Khamsamīya in 1497. That is the only historical account described in the work, and besides the siege passage, the book contains

33 Ibn Iyās, Badā’ic vol. 3, p. 397; Ibn Iyās, Histoire, p. 440.

34 Ibn Iyās, Badāi íc vol. 3, pp. 339, 397, 406; Ibn Iyās, Histoire, pp. 379, 440, 448.

35 For example, David Ayalon mentions as reasons of al-Nāșir Muḥammad b. Qāytbāy's downfall his "unstable character, his being the son of a Mamluk and not himself a Mamluk, the great contrast between him and his illustrious father", see: Ayalon, Gunpowder and Firearms in the Mamluk Kingdom, p. 71. Garcin speaks of a "fifteen year old sultan who was said to be unbalanced", see: Garcin, "The regime of the Circassian Mamluks", p. 296. Loiseau describes the beginning of his reigns as follows : "Son avènement en 1496 à lâge de quatorze ans ouvrit une période d'instabilité et d'affrontements qui se solda par son assassinat deux ans plus tard", see Loiseau, Les Mamloukes, XIIIe-XVIe siècle, p. 135. Haarmann explains the revolt against Qāytbāy by his outrageous recruitment of black slaves, although these units must have existed prior to his ascendance to the throne, see: Haarmann, "Der arabische Osten", p. 252.

36 Ibn al-Ḥimṣī, Hawādith, vol. 2, pp. 9-59; Ibn Ṭūlūn, Mufākahat, pp. 167-205. 
eulogies on the virtues of the young sultan. The final part also contains a collection of sixteen dreams that all predict the victory of al-Nāșir Muhammad b. Qāytbāy. ${ }^{37}$ The existence of such a work hints at the fact that there had been feelings of sympathy towards Nāṣir Muhammad b. Qāytbāy in the Sultanate and that he was not as negatively seen as other sources portray him.

The story of the rise and decline of the young sultan even fascinated European travelers. The German knight and pilgrim Arnold von Harff visited Cairo in the aftermath of the defeat of Qānșūh al-Khamsamìya. His work contains the only existing drawing of al-Nāṣir Muhammad b. Qāytbāy (see figure 4.1). During his stay in Cairo, von Harff speaks about court politics, which he has apparently discussed in wine-drinking sessions with two German-speaking mamlüks he met in Cairo. Von Harff describes how, according to his informants, since the time of the biblical Joseph, who had been sold by his brothers, sultans had to have roots in slavery, heathendom and foreign origins. Nevertheless, this young sultan had now challenged that tradition and so far fought off all his enemies. However, at the time when he wrote down his travel experience back home in Germany, von Harff was wondering what might have happened to the young sultan in the meantime. ${ }^{38}$

The Northern Italian religious scholar Petrus Martyr Anglerius already knew something about the fate of al-Nāșir Muhammad b. Qāytbāy, when he visited Egypt in 1501/2. In Egypt he acted as Spanish envoy and tried to convince Sultan Qānșūh al-Ghawrī that the conquest of Granada was in fact an internal matter for the Spanish and should not hamper the traditional good relations between Spain and the Sultanate..$^{39}$ Of high interest for the present chapter is Anglerius' portrayal of the turbulent reign of al-Nāṣir Muhammad b. Qāytbāy. According to Petrus Martyr Anglerius the old Sultan Qāytbāy had never consented to the succession of his son as he feared for his son's life. The amirs, however, had at first agreed to put the young son on the throne, as they had no clear favorite among them. Therefore, Muhammad was declared sultan by the Egyptian High Priest ("a summo eorum pontifice"), i.e. the caliph. However, the young sultan then misbehaved badly from the beginning of his reign. $\mathrm{He}$ planned to kill all his enemies at a banquet, even including his uncle. This plan was indeed so horrible that his mother revealed it to her brother Qānșūh. Qānșūh then had Muhammad killed and used his personal network to become

37 Ibn Shihna, al-Badr al-zāhir; see for a description of author and manuscript: Holt, "Literary offerings", pp. 12-13.

38 Von Harff, Die Pilgerfahrt des Ritters Arnold von Harff, pp. 86-89.

39 Anglerius, Legatio Babylonica, pp. 53-55. 
the new sultan. ${ }^{40}$ We do not have the exact source of this information but it might be that the Spanish-born Taghri Birdī, the well-known translator (dragoman) of the royal court in Cairo might be behind this official information as he was in contact with the envoy. ${ }^{41}$

Al-Nāṣir Muhamammad b. Qāytbāy and his supporters knew that staying in power was a difficult task for a sultan's son in the fifteenth century. In this context it is a matter of speculation whether his father Qāytbāy was behind the plan to stay in office, or not. However, the fact that he placed his son as a simple recruit in the barracks might hint at the fact that Qãytbāy indeed wanted his son to become his successor or at least a full member of the military elite. When al-Nāșir Muhammad b. Qāytbāy and his circle then decided to assume power, it seems quite a logical move to evoke the image of al-Nāșir Muhammad b. Qalāwūn as a case in point for the rule of a sultan's son. Sultan al-Nāșir Muhammad b. Qalāwūn had managed to become a very powerful sultan in the early fourteenth century, despite being the son of a sultan and not being imported as a military slave at a young age. Twice al-Nāșir Muhammad b. Qalāwūn had been installed as a sultan at an early age by the amirs of his father and twice he had again lost power. When he finally ascended the throne for the third time in 1310 at the age of 25 he experienced a long and stable rule from 1310 to 1341. Amalia Levanoni has written a substantial monograph on al-Nāșir Muhammad b. Qalāwūn, and she explains his success by the fact that he undermined the existing traditions of the old members of the military elite through a number of reforms, yet at the same time gathered enough support from other parts of the military establishment especially among the young soldiers, so that his controversial reforms could be successful. ${ }^{42}$ More recently, Jo Van Steenbergen and Willem Flinterman have argued that the power transition under al-Nāșir Muhammad b. Qalāwūn, from elder grandees of his father who were pushed aside by him to form a new entourage, might have been smoother than Levanoni suggested. Muhammad b. Qalāwūn was helped in changing the elites by his family network and a more docile and ambitious generation of younger amirs who had spent their career with him. In addition to this he gathered around him

\footnotetext{
$40 \quad$ Anglerius, Legatio Babylonica, pp. 26o-263.

41 On Taghrī Birdī, see: Anglerius, Legatio Babylonica, pp. 81-91.

42 Levanoni, A Turning point in Mamluk History, pp. 29-80. (Chapter two: Undermining traditions).
} 
ambitious mamlüks of a similar age to him who had depended on Muhammad b. Qalāwūn's sultanic predecessors or defeated rivals. As their former masters were out of favor or dead the career outlooks of these younger mamlüks had been bleak; therefore, they were ready to support al-Nāșir Muhammad b. Qalāwūn when he offered them unexpected new opportunities. ${ }^{43}$

Remarkable parallels appear when we realize that in the late fifteenth century al-Nāṣir Muhammad b. Qāytbāy tried to pursue the same path as al-Nāṣir Muhammad b. Qalāwūn in the fourteenth century, with a young entourage bolstered with the support of middle-aged amirs in order to get rid of the elder grandees of his father. Similar to the initial experiences of his famous namesake, however, the young Muhammad b. Qāytbāy's chances of success were rather bleak. The grandees of his father never seem to have considered the actual possibility that he might stand in office for long. As depicted above they had already started the power race by fighting amongst themselves; they did not expect to be rivalled by the young sultan. The young sultan therefore had to make a symbolic entrance in the game by literally "throwing his hat in the ring" in order to be taken seriously as a contender.

However, before declaring his claim, he had to choose a regal name. According to Ibn Iyās the honorary name (laqab) "al-Manșūr" was briefly considered for unknown reasons. "Al-Manșūr" might have pointed to the father of al-Nāșir Muhạmmad b. Qalāwūn, sultan al-Manșūr Qalāwūn (r. 1279-1290), but the name al-Nāșir was soon chosen to legitimize the dynastic claim. ${ }^{44}$ Still, in the beginning the use of the royal style al-Nāșir appears not really to have been seen as provocative for the establishment. However, the first uproar was soon to come as al-Nāṣir Muhammad committed what was considered outrageous behavior.

One month after the death of his father, in September 1496 [Muharram of 902], al-Nāṣir Muhammad b. Qāytbāy appeared at the Friday prayer with something on his head which clearly shocked the present amirs. Ibn Iyās reports: "The peak of the fickleness of al-Nāṣir Muhammad was that he went to the

43 Flinterman and Van Steenbergen, "Al-Nasir Muhammad and the formation of the Qalawunid State", pp. 95-98 ('The Social Production of al-Nasir Muhammad's State').

44 Ibn Iyās, Badā'i $i$ vol. 3, p. 333; Ibn Iyās, Histoire, p. 372. However, in the turmoil of the fighting against Qānșūh al-Khamsamiya at the beginning of 1497 young mamlūk soldiers demanded that he should change his name from al-Nāșir to al-Ashraf like his father. The reason was that they felt disfavored when they carried the common name al-Nāșiinya, which identified them as being bought by the young sultan instead of the Ashrafiya of Qāytbāy. According to Ibn Iyās the soldiers achieved the change, but it does not seem that al-Ashraf was really used in any context, see: Ibn Iyās, Badā̇ic vol. 3, p. 351; Ibn Iyās, Histoire, p. 391. 
Friday prayer without wearing a kallawta on his head, instead he wore only a takhfifa șaghira and this shocked the amirs and they harshly criticized such a behavior". ${ }^{45}$ However, the amirs did not limit themselves to verbal criticism. One month later, the highest ranking amirs, the commanders of a thousand, reacted in a very creative way: through fashion. They brought out a new headgear, modifying the official so-called takhifa kabira ('the greater lighter one') by putting horns on it. ${ }^{46}$ According to Ibn Iyās the amirs said that this new headgear arrangement was inspired by Dhū al-Qarnayn, the two-horned hero of the Quran [18: 83-98], who is commonly identified as Iskandar, or Alexander the Great, considered by contemporaries as the prototype of the Muslim hero. Veneration of Alexander had become increasingly popular in the fifteenth century, especially through the Iskandername of the Ottoman poet Ahmadi (d. 1413) ${ }^{47}$ Ibn Iyās explains in another more detailed passage about the royal role of takhfifa kabira: "It nowadays takes the place of the crown of the kings of Egypt; with it the Turks show their might. It was worn by the Persian kings before" (see also figure 4.2). ${ }^{48}$

Although one might downplay the effects of these clothing issues, one has to bear in mind that Syro-Egyptian society was highly ritualized when it came to public outings of the Sultanate's leaderships. Changes of style were therefore very meaningful. The intention of the leading amirs may well have been to show the young sultan that their rights to power were far better founded than his. Still this was not the end of the dispute. Al-Nāșir Muhammad b. Qāytbāy showed them afterwards publicly what he thought about their new headgear creation. In the month of April 1497 [Shabān 902] shortly after he had defeated Qānșūh al-Khamsamīya, so Ibn Iyās narrates, he bestowed the takhfífa with horns on Wafā, a gardener. Needless to say, in his report Ibn Iyās expressed outrage at this, as Wafā was one of the common people who should wear the simple turban. ${ }^{49}$

In the context of headgear, it is interesting to note that in the early fourteenth century al-Nāșir Muhammad b. Qalāwūn had also had renewed facets of the official headgear. Around the end of the thirteenth century the color of the so-called kallawta cap switched from yellow to red. Mamlük soldiers and amirs then started wrapping a turban around the kallawta. This new arrangement became the official headgear under al-Nāșir Muḥammad b. Qalāwūn and

45 Ibn Iyās, Badā’ic vol. 3, p. 339; Ibn Iyās, Histoire, p. 379.

46 Ibn Iyās, Badā̇ic vol. 3, p. 340; Ibn Iyās, Histoire, p. 380.

47 Ibn Iyās, Badā̇i vol. 3, p. 340; Watt, "al-Iskandar"; Abel, "Iskandar Nāma".

48 Ibn Iyās, Badāंic vol. 4, p. 332.

49 Ibn Iyās, Badā’i . vol. 3, p. 359; Ibn Iyās, Histoire, p. 400. 


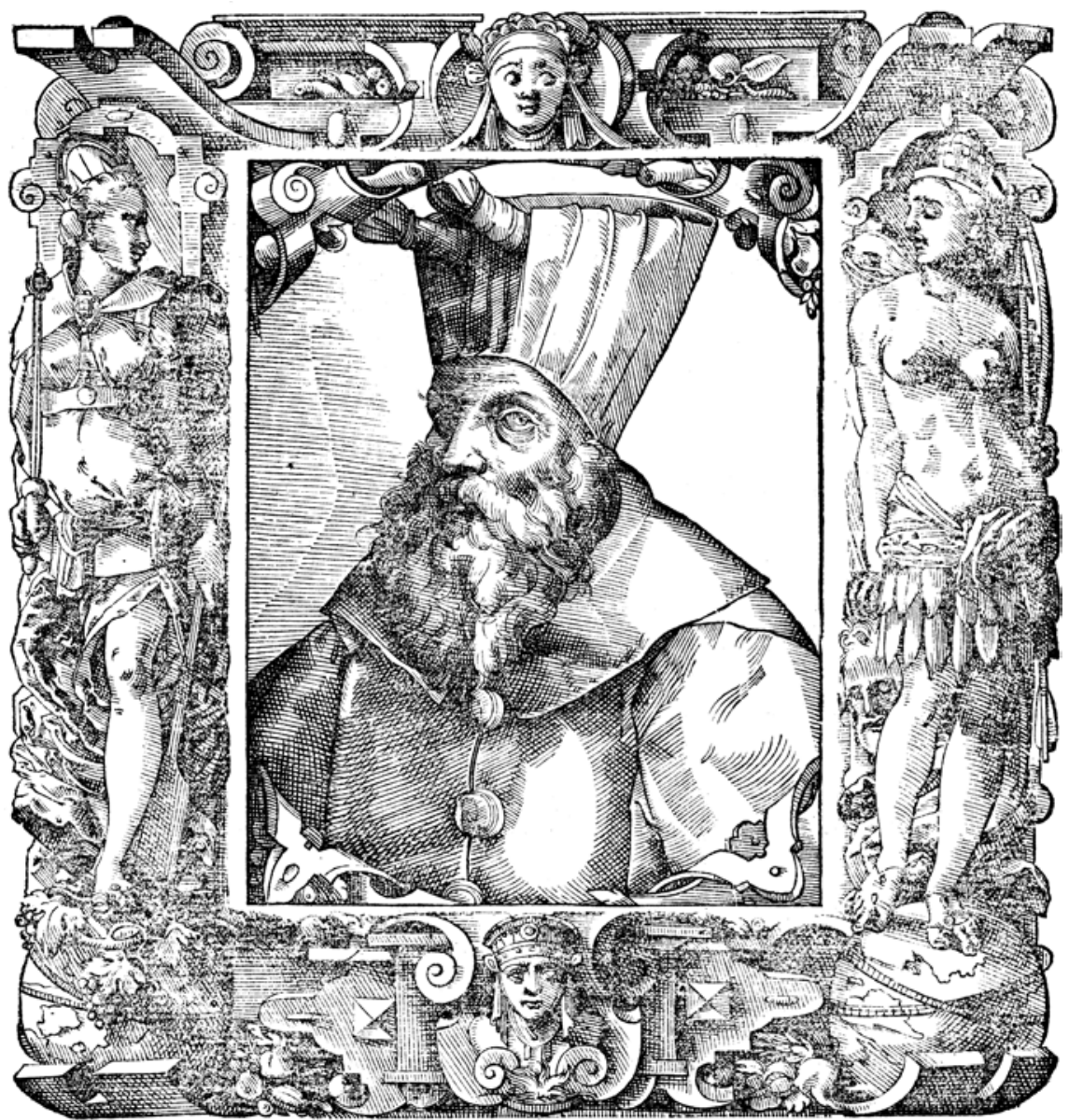

FIGURE 4.2 Sultan Qānșūh al-Ghawrī (r. 1501-1516) wearing the Takhfífa Kabìra GIOVIO, VITAE ILLUSTRIUM VIRORUM, P. 221

the old-style tricorn sharbūsh worn by earlier sultans went out of fashion. ${ }^{50}$ While it seems that the initial change from yellow to red had already been ordered by al-Nāșir Muhammad's brother Sultan al-Ashraf Khalīl (r. 1290-1293), the kallawta-cap arrangement with the turban grew much bigger in size and was also of better quality during his own long reign. It was then combined with another innovation. In 732/ $133^{2}$ al-Nāṣir Muhammad b. Qalāwūn went on pilgrimage and had his head completely shaven. After coming home, he kept his bald head instead of growing back the long hair that used to fall down loosely

50 Al-Maqrīīi, al-Mawāiz wa-al-itibār, vol. 3, p. 328. 
on the neck, as was the custom. According to the secretary al-Qalqashandī this look was then copied by his entourage and he became a trendsetter. ${ }^{51}$

As there is a lack of direct evidence here one can only speculate that there exists a direct connection between the two headgear changes of al-Nāșir Muḥammad b. Qalāwūn and al-Nāṣir Muḥammad b. Qāytbāy. But given the wider context and the argumentation of this chapter, it seems likely that alNāșir Muḥammad b. Qāytbāy might have heard of the fashion acts of his namesake and wanted to make a political statement through similar symbolic actions.

Another point where we can find interesting similarities between the two leaders is in the field of military reform. Sultan al-Nāșir Muhammad b. Qalāwūn undertook several changes in the military organization of his realm. Perhaps the most famous of these was his reform (sg. rawk) of the iqtā ${ }^{c}$ system used for the remuneration of the army. He rearranged the system in order to generate more income for the sultan and his central apparatus of power. The income of the leading amirs was thereby diminished as they received less $i q t \underline{a} \bar{c}^{c}$ land than before. ${ }^{52}$

In the case of al-Nāṣir Muhammad b. Qāytbāy we see similar actions used to create ties with mamlūk leaderships. An example is the land tenure privileges at the early beginning of his reign, when he was still much endangered by the activities of Qānșūh al-Khamsamìya. In August 1496 (Dhū al-hijjja 9o1) Muhammad b. Qāytbāy is said to have distributed to mamlūk amirs around 1,00o iqțās which had previously belonged to the dhakhira (treasure/ source of royal income $)^{53}$, the reserve of his father. He therefore opened up the royal resources in order to buy loyalty. ${ }^{54}$ We do not know who actually benefitted from this act in reality, however it is one of the few measures taken by the young sultan about which we do not hear any complaints by Ibn Iyās.

Quite the contrary holds true for another action undertaken by al-Nāșir Muhammad b. Qāytbāy which according to Ibn Iyās constituted an abominable act, and was something no sultan had ever done before. What had happened? In January 1498 (Jumādā I 903) al-Nāṣir Muḥammad b. Qāytbāy had ordered an increase in the number of mamlüks which each amir had to maintain. The

$5^{1} \quad$ al-Qalqashandī, Șubh al-'ashä, vol. 4, pp. 39-40, See on the issue of Mamluk headgear: Fuess, "Sultans with Horns".

52 See: Sato, State and Rural Society in Medieval Islam; Levanoni, A Turning Point, pp. 53-6o.

53 See for the meaning of the term dhakhïra under Sultan Qāytbāy: Igarashi, Land Tenure, Fiscal Policy, p. 129.

54 Ibn Iyās, Badā̇ic vol. 3, p. 335; Ibn Iyās, Histoire, p. 374. Ibn Shiḥna, al-Badr al-Zāhir, p. 51. See for the question of the sultanic fisc: Daisuke, Land Tenure, Fiscal Policy, pp. 121-138 (especially p. 131 on al-Nāșir Muḥammad b. Qāytbāy). 


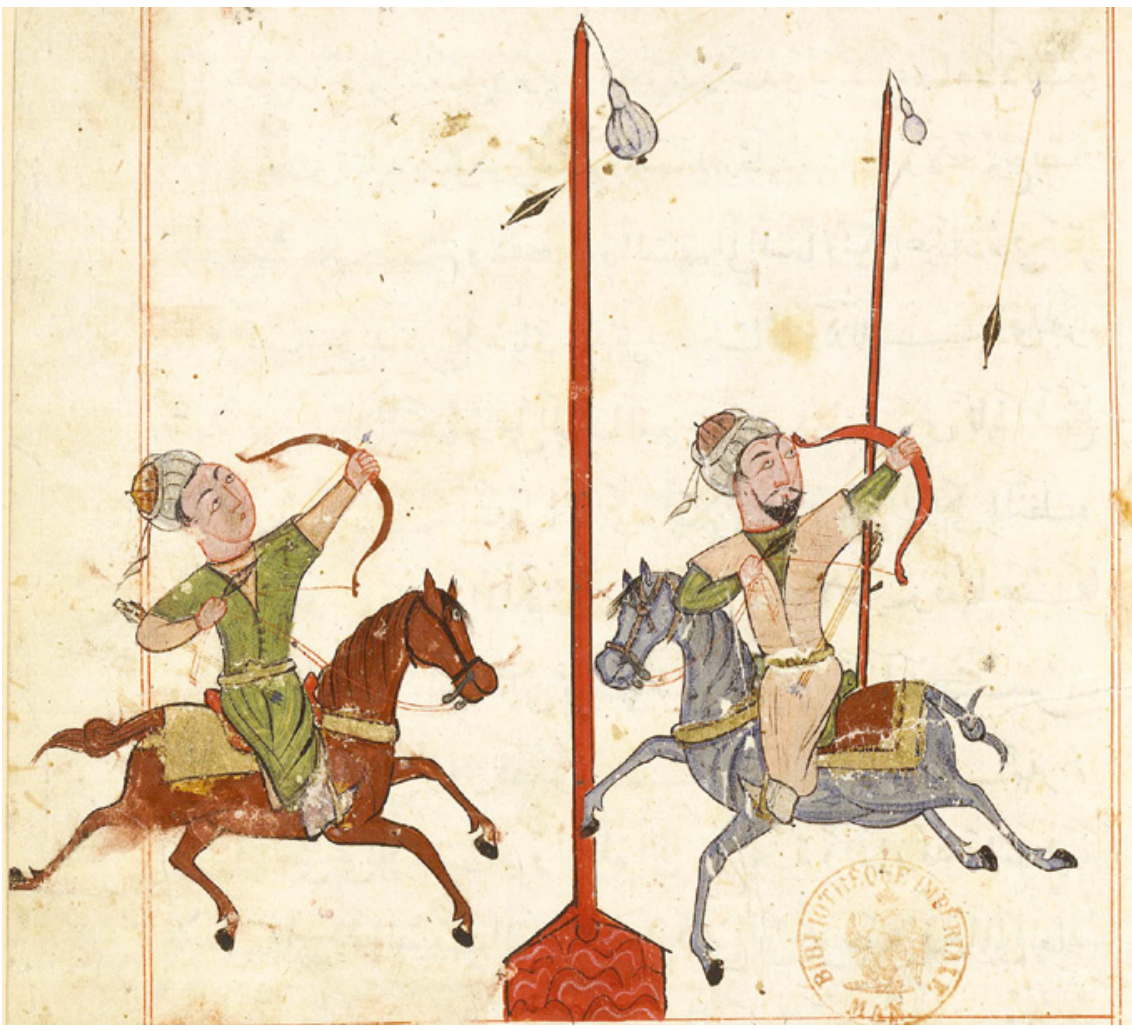

FIGURE 4.3 Mamluk soldiers wearing the red kallawta cap with turban, 1470 PARIS, BIBLIOTHÈQUE NATIONALE, MS ARABE 282, IBN AKHĪ KHUZAM, KITĀB AL-MAKHZŪN JĀMI' AL-FUNŪN, FOL. 28

"commanders of thousand"55 had to finance an additional 30, the "amirs of 40" had to sustain 10 more and the "amirs of 10 " had to bring an additional five..$^{56}$ However, the financial resources of the amirs were not augmented to compensate for this, so this actual growth of their financial burden by $30 \%$ was a hard blow for the amirs. Once again one could speculate that both actions concerning land tenure resonated with the practice of al-Nāșir Muhammad b. Qalāwūn in the sense that the latter had earlier also tried to assure loyalties by giving

55 The amir of 100 mamlūk horsemen and 1,00o infantrymen (amìr mi'a wa-muqaddam alf) represented the highest rank in the military hierarchy. As the name suggests, he usually had to equip 100 mamlüks. There were a maximum of 24 commanders of 1,00o at the same time and the highest position in the state were exclusively drawn from among them. The amir of 40 commanded 40 mamlüks and the amir of 10 accordingly 10.

Ibn Iyās, Badā’í vol. 3, p. 385; Ibn Iyās, Histoire, p. 425. 
presents, and only later had he reformed the system in order to get a firmer financial grip on the amirs.

In general, raising money was a necessity in 1496 . At that time the Sultanate needed additional resources to combat the external threat represented by the expanding Ottoman Empire, especially in the field of new military techniques and the use of guns and firearms. ${ }^{57}$ As already stated above, the son followed a path in these reforms which his father had first taken in order to strengthen his military force. The young sultan, however, appears to have wanted to also use the opportunity to overthrow the old elite with the help of the new units. It actually was a unit of black slaves with rifles that helped the young sultan win the wars against the amirs Qānșūh al-Khamsamīya and Āqbardī. When the sultan descended from the citadel into town he was usually accompanied by his cousins Jānibak and Jānim and a troop of black slaves with rifles marching in front of them. ${ }^{58}$ This not only raised the anger of the amirs, but even the young mamlük soldiers were not too happy to share their important role and economic resources in the state with black slaves whom they looked down on because of prevalent forms of racial stereotyping. ${ }^{99}$

Ibn al-Himsì presents us with a report of an event which highlights this rivalry. According to this story, in February of 1498 [Jumādā II 903], the young sultan gave Faraj Allāh, who was the chief of the black slave rifle squadron, the right to wear clothes and headgear originally reserved for the mamlük military elite and also gave him the right to marry a white Circassian slave girl. When the mamlüks of the young sultan saw this, they took to their arms and killed Faraj and 50 of the 500 black slaves, and in the fight lost only two of their own. After this incident al-Nāṣir Muhammad's advisors persuaded the sultan to stop equipping black slaves with rifles and to abstain from nocturnal outings with them. He promised to sell the black slaves to the Turkmen. ${ }^{60}$ If this story is true it was a serious setback for the sultan. According to this version, not only did

57 Ibn Iyās, Badā'ic, vol. 3, p. 269, footnote 14; see for the issue of Mamluk firearms: Fuess, "Les Janissaires, les Mamlouks et les armes à feu".

$5^{8} \quad$ Ibn Iyās, Badā̇ic vol. 3, p. 387; Ibn Iyās, Histoire, p. 427.

59 Unfortunately it is unclear how much they earned. In principle of course they were slaves but there had to be a kind of renumeration. We know for example that Sultan Qāytbāy had a firearm unit formed out of sons of mamlüks (the so-called awläd al-nās) at the beginning of the 1490 s and they received only half of the monthly payment of a full mamlük soldier, i.e. 1,00o dirhams compared to 2,00o dirhams, see: Ayalon, Gunpowder, 65. Of course the contemporary racism meant that black slaves would have to do it for much a lower payment; but in my opinion it is improbable that they would have served without any salary even given their slave status. It is hard to imagine giving a slave a gun and then expecting service for free.

6o Ibn al-Ḥimṣī, Hawādith, vol. 2, pp. 36-37. 
he lose an important pillar for his military plans but he also had to balance his young mamlüks with the new unit of black slaves in order to counterbalance the veteran amirs. This was certainly a very difficult task.

Be it as it may, this episode did not bring about the end of infantry units of black slaves with guns in the Sultanate's army. In fact, the Sultanate's leadership tried to acquire as many guns as possible in order to compete with the Ottomans. As black slaves were the cheapest slaves on the market and guns were easy to handle compared to other contemporary weapons, for obvious economic reasons the gun-carrying infantry units continued to be composed of black slaves. One case in point is the aforementioned powerful amir Kurtbāy al-Ahmar ("The Red") who was appointed as governor of Damascus. At the beginning of the year 904 [August 1498], al-Ahmar ordered the people of Damascus to provide him with money and black slaves. He then trained a large group of black slaves to use firearms and formed a unit which upheld public security. Apparently because of his nickname "the red" they wore red clothes and red caps. ${ }^{61}$ There was therefore an ongoing continuity in the gun business and the black slaves using them. We hear for example of 500 black slaves with guns who were sent by Sultan Qānșūh al-Ghawrī on a military expedition to the Hijaz in the spring of 1503 (Shawwāl 908). ${ }^{62}$

\section{5} Looking for Allies

As argued above, when al-Nāșir Muhammad b. Qāytbāy deliberately took on the old elite he somehow stepped into the footsteps of his namesake of the fourteenth century. As was described above, he engaged in direct confrontations with these veteran amirs, leaving the first of his powerful opponents dead and forced the second to flee to Northern Syria. The third very powerful amir, Kurtbāy al-Ahmar, seems to have stayed loyal, but the sultan preferred to send him away from Cairo as governor of Damascus.

Nonetheless, in order to carry out his plans to oust the old guard from power and go on with his reforms he would have needed more support than a unit of black slave soldiers could provide. He tried to bolster his power base in two ways. The first was to get the populace behind him. The second was to create a personal network of family, friends and military comrades. It seems that he succeeded in the first aim. He gained a positive image among the common people, as even Ibn Iyās had to admit. Although Ibn Iyās comments that the

61 Ibn Ṭūlūn, Mufākahat, vol. 1, p. 201.

62 Ibid., pp. 17-173. 
young sultan did only evil things during his numerous outings, it seems that al-Nāșir Muḥammad b. Qāytbāy gained popularity by his public appearances especially by making the public space safe which had been hard hit by the two subsequent military sieges of the citadel. At one point in his account Ibn Iyās remarks that the young man was not bothered about acting with the dignity of his office, as his predecessors had done, and that he behaved like an ordinary policeman instead. ${ }^{63}$

As a result, it seems that he succeeded in restoring public order. However, he clearly misjudged the reliability of his family network. As he openly promoted a legitimacy based on family ties from father to son he needed the support of all family members. His closest allies were his two cousins Jānibak and Jānim who were later killed with him. Then there were mamlük comrades who, just like his two cousins, had gone with him to the barracks. He might therefore have gained the support of the young mamlük soldiers who were of his age. He even actively promoted some of these. One example can be seen in a young man with the name of Qānșūh b. Sultan Jarkass who was appointed at the beginning of 1498 to the office of Häjib (chamberlain) of Damascus. This was seen as exceptional because of his very young age. ${ }^{64}$ Moreover, he regularly promoted members of his family to higher ranks as in the case of his maternal uncle Qānșūh. It seems that his mother was also active behind the scene to get alliances working. ${ }^{65}$

However, he did misjudge his family network as ultimately two members of his family would fail him. The first was the cousin of his father, the Great Dawādār Āqbardī, who besieged al-Nāṣir Muḥammad b. Qāytbāy in the citadel. According to Ibn Iyās, Āqbardī had stated that it was nothing personal and argued publicly that he did not fight the young sultan but only his bad advisors who belonged into prison. ${ }^{66}$ This time around al-Nāșir Muhammad b. Qāytbāy could overcome the threat, but with his maternal uncle Qānșūh things turned out differently. Although al-Nāṣir Muhammad b. Qāytbāy had promoted Qānșūh to high office after their common military victories, they fell out for unknown reasons and as we have seen, not even Așalbāy the mother of the sultan could breach the rift. Qānșūh was finally convinced by other amirs (seemingly from the reconciled households of Qānșūh al-Khamsamìya and Āqbardī) to get rid of al-Nāṣir Muhammad b. Qāytbāy. The price they had to offer was something

63 Ibn Iyās, Badā̇ic vol. 3, p. 387; Ibn Iyās, Histoire, p. 427.

64 Ibn Ṭūlūn, Mufākahat, vol. 1, p. 203.

65 Ibn Iyās, Badā̃i. vol. 3, p. 361; Ibn Iyās, Histoire, p. 401.

66 Ibn Iyās, Badā’ic vol. 3, p. 366; Ibn Iyās, Histoire, p. 407. 
which al-Nāṣir Muhammad b. Qāytbāy would never offer to Qānșūh, i.e. the sultanate. ${ }^{67}$

The wish to conclude alliances could also be felt in external relations. An Ottoman source speaks of a marriage project between one of the daughters of the Ottoman Sultan Bayezid (r. 1481-1512) and al-Nāșir Muhammad b. Qāytbāy. This would obviously have strengthened the young sultan's position. Bayezid might have preferred to marry his daughter to a young sultan of dynastic lineage instead of an old sultan who had started his life as a slave. ${ }^{68}$ After the assassination of al-Nāṣir Muḥammad b. Qāytbāy Sultan Bayezid apparently protested in a hefty manner and showed his disappointment. ${ }^{69}$

\section{6}

\section{Conclusion}

The reign of al-Nāṣir Muhammad b. Qāytbāy represented a troublesome period full of fighting and deceit. Thanks to Ibn Iyās, Al-Nāṣir Muḥammad has a very negative image and he is perceived in historiography as having played only a minor role. However, al-Nāșir followed up on reforms especially in the military sector which his father Qāytbāy had already begun. These initiatives were then continued by his successors, because the circumstances of this time period simply required them. What went against him was that, at the end of the fifteenth century Mamluk military society had become very reluctant to hand power over to an inexperienced juvenile.

Parallels with the image of al-Nāṣir Muhammad b. Qalāwūn, or what contemporaries thought they knew about that figure, may perhaps have helped al-Nāșir Muḥammad b. Qāytbāy to counter any accusations of a lack of experience. Al-Nāșir Muhammad b. Qāytbāy and his entourage knew they had to be wary of the grandees of his father and had to build a network of powerful people, but, unfortunately, they could not get enough people to back them for long enough. Nevertheless, as his reign represents the longest of any ruling son of a sultan after the reign of al-Nāșir Faraj b. Barqūq (r. 1309-1405; 1405-1412) at the beginning of the fifteenth century, this might still count as a kind of a success.

Despite all the parallels and similarities, al-Nāṣir Muḥammad b. Qāytbāy did not develop into a second al-Nāṣir Muḥammad b. Qalāwūn. However, Ibn Iyās remarks, the former's career and death did resemble that of the brother of the

67 Ibn Iyās, Badā’ic vol. 3, p. 400; Ibn Iyās, Histoire, p. 443.

68 Muslu, The Ottomans and the Mamluks, p. 161.

69 Muslu, The Ottomans and the Mamluks, p. 161; Ibn Iyās, Badāं ic vol. 3, p. 411; Ibn Iyās, Histoire, p. 453 . 
latter and another son of Qalāwūn, al-Ashraf Khalīl (r. 1290-1293), who was also slain by rival amirs while hunting near Giza. ${ }^{70}$ Therefore al-Nāṣir Muhammad b. Qāytbāy followed the model of at least one son of Qalāwūn right to the end. Seen from his personal perspective this was certainly the wrong model to follow. In any case it is remarkable that Ibn Iyās mentions this unsuccessful son of Qalāwūn in the context of the death of al-Nāṣir Muḥammad b. Qāytbāy, because he actually seems to have tried in vain to copy the other son, his famous namesake. The young sultan might even have been equally successful if not for the fact that at the end of the fifteenth century the dynastic principle was over for good and the Sultanate was fully "mamlukized". The old mamlük elite proved unwilling to accept the attempts of a sultan's son to conquer the throne by a total replacement of old rituals and institutions. Therefore, that mamlük elite prevailed and in 1501, the succession crisis was finally ended by Sultan Qānșūh al-Ghawrī (r. 1501-1516), a member of the traditional elite. What is remarkable is that al-Ghawri had to continue the path of reforms because of the Ottoman threat. There was simply not the possibility to keep the status quo. Still as Qānșūh al-Ghawrī had been the successful candidate of the "deep Mamluk state", his reforms were disliked but much less contested as he did not challenge the system as a whole.

\section{Bibliography}

\section{Primary Sources}

Al-Maqrīzī, al-Mawāiz wa-al-ítibār fì dhikr al-khițaț wa-l-āthār, Ayman Fu’ad Sayyid, ed., 6 vols. (London: al-Furqān li-l-Turāth al-Islāmī, 2002-2004).al-Qalqashandī, Șubh al-ashhā fi șināáat al-inshā, s.e., 14 vols (Cairo: al-Mațba'a al-Amïriyya, 1913-1920).Anglerius, Petrus Martyr, Legatio Babylonica. Die Gesandtschaft nach Babylon, Hans Heinrich Todt, ed., transl. comm. (Wiesbaden: Harrassowitz 2015).

Giovio, Paul, Vitae Illustrium virorum: tomis duobus comprehensae, \& proprijs imaginibus illustratae (Basel 1578).

Ibn al-Ḥimșī, Ḥawādith al-zamān wa-wafíyāt al-shuyūkh wa-l-aqrān, 'Umar 'Abd alSalām Tadmurī, ed., 3 vols,( Beirut: al-Maktaba al-Așriyya 1999).

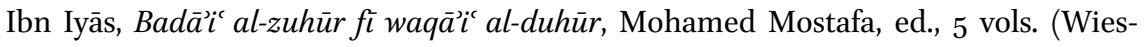
baden: Franz Steiner 1960-1975).

Ibn Iyās, Histoire des Mamlouks Circassiens, Gaston Wiet, transl., 2 vols. (Cairo: Imprimerie de l'Institut Français d'Archéologie Orientale 1945).

Ibn Shiḥna, al-Badr al-zāhir fì nuṣrat al-Malik al-Nāṣir, 'Umar 'Abd al-Salām Tadmurī, ed. (Beirut: al-Maktaba al-'Așriyya 1983). 
Ibn Ṭūlūn, Mufākahat al-khillān fì ḥawādith al-zamān, Mohamed Mostafa, ed., 2 vols.

(Cairo: Dār Ihyā̄' al-Maktaba al-'Arabiyya, 1962).

Von Harff, Arnold, Die Pilgerfahrt des Ritters Arnold von Harff, wie er sie in den Jahren 1496-1499 vollendet und durch Zeichnungen erläutert hat, Eberhard von Groote, ed. (Hildesheim: Georg Olms 2004).

\section{Secondary Sources}

Abel, Armand , "Iskandar Nāma", in The Encyclopedia of Islam, 2nd edition, vol. 4 (Leiden: Brill 1987), pp. 127-129.

Apellániz Ruiz de Galarreta, Francisco J., Pouvoir et finance en méditerranée prémoderne: le deuxième état mamelouk et le commerce des épices (1382-1517) (Barcelona: Consejo Superior de Investigaciones Cientificas, 2009).

Ayalon, David, Gunpowder and Firearms in the Mamluk Kingdom. A Challenge to a Medieval Society (London: Frank Cass, 1978).

Flinterman, Willem, Jo Van Steenbergen, "Al-Nasir Muhammad and the Formation of the Qalawunid State", in A. Landau, ed., Pearls on a String: Artists, Patrons, and Poets at the Great Islamic Courts (Seattle: Walters Art Museum and University of Washington Press, 2015), pp. 86-113.

Fuess, Albrecht, "Les Janissaires, les Mamlouks et les armes à feu. Une comparaison des systèmes militaires ottoman et mamlouk à partir de la moitié du quinzième siècle”, Turcica, 41 (2009): 209-227.

Fuess, Albrecht, "Sultans with Horns. About the Political Significance of Headgear in the Mamluk Empire", Mamlūk Studies Review 12/2 (2008): 71-94.

Garcin, Jean-Claude, "The Regime of the Circassian Mamluks", in C. Petry, ed., The Cambridge History of Egypt. I: Islamic Egypt, 640-1517 (Cambridge: Cambridge University Press, 1998), pp. 290-317.

Haarmann, Ulrich, "Der arabische Osten im späten Mittelalter, 1250-1517", in U. Haarmann, ed., Geschichte der arabischen Welt (München ${ }^{4}$ : Beck 2001), pp. 217-263.

Har-El, Shai, Struggle for Domination in the Middle East. The Ottoman-Mamluk War, 1485-1491 (Leiden 1995).

Holt, Peter M., "al-Nāṣir."in: The Encyclopaedia of Islam, 2nd edition (Leiden: E.J. Brill, 1993), pp. 991-993 (Brill Online, http://dx.doi.org/10.1163/1573-3912_islam_ COM_0852).

Holt, Peter M., "Literary offerings: a genre of courtly literature", in Th. Philipp \& U. Haarmann, eds. The Mamluks in Egyptian politics and society (Cambridge: Cambridge University Press, 1998), pp. 3-16.

Igarashi, Daisuke, Land Tenure, Fiscal Policy, and Imperial Power in Medieval Syro-Egypt (Chicago: Middle East Documentation Center, 2015).

Levanoni, Amalia, A Turning Point in Mamluk History. The Third Reign of al-Nāṣir Muhammad b. Qalāwūn 1310-1341 (Leiden: Brill, 1995). 
Loiseau, Julien, Les Mamelouks:XIII -XVIe siècle: une expérience de pouvoir dans l'Islam médieval (Paris: Editions du Seuil, 2014).

Muslu, Cihan Yüksel, The Ottomans and the Mamluks. Imperial Diplomacy and Warfare in the Islamic World (New York: Palgrave Macmillan, 2014).

Petry, Carl F., "The Military Institution and Innovation in the Late Mamlūk Period", in C. Petry, ed., The Cambridge History of Egypt. I: Islamic Egypt, 640-1517 (Cambridge: Cambridge University Press, 1998), pp. 462-489.

Sato, Tsugitaka, State and Rural Society in Medieval Islam. Sultans, Muqta's and Fallahun (Leiden: Brill, 1997).

Sievert, Henning, Der Herrscherwechsel im Mamlukensultanat. Historische und historiographische Untersuchungen zu Abū Hāmid al-Qudsī and Ibn Tağribirdī (Berlin: Klaus Schwarz, 2003).

Van Steenbergen, Jo, Patrick Wing, Kristof D'hulster, “The Mamlukization of the Mamluk Sultanate? State Formation and the History of Fifteenth Century Egypt and Syria. Part II: Comparative Solutions and a New Research Agenda", History Compass 14/11 (2016): 560-569.

Van Steenbergen, Jo, Patrick Wing, Kristof D'hulster, “The Mamlukization of the Mamluk Sultanate? State Formation and the History of Fifteenth Century Egypt and Syria. Part I: Old Problems and New Trends", History Compass 14/11 (2016): 549-559.

Watt, W. Montgomery, "al-Iskandar", The Encyclopedia of Islam, 2nd edition, vol. 4 (Leiden: Brill 1987), p. 127. 